\title{
Improving Internationally Core Competences Based on the Capabilities of Precise and Accurate Project Management
}

\begin{abstract}
Modern international project management has entered the phase of precise and accurate project management after the global financial crisis broke out at the beginning of the $21^{\text {st }}$ century. However, its development has faced new challenges since there has been lack of explicitly unanimous definition for the capability dimensions of precise and accurate project management, as well as the models and their process control parameters. The required core capabilities based on the precise and accurate project management for various rings are involved in the project life cycle, namely, the required internationally core competences and their components for the phases of project strategic planning and decision making in the early project phase, as well as the value engineering, and the project supervision and controls during the execution phase. Through studying the effects of the internationally core competences based on precise and accurate project management capabilities for the success and excellence of projects and configuring such models, the goal is to help the main contractors continuously obtain project success and excellence, thus improve its internationally core competences with continuous project success and excellence.
\end{abstract}

Keywords: precise and accurate project management, project strategic planning, decision-making, project supervision and controls, project execution, value engineering

Manuscript received April 11, 2016; accepted August 20, 2016

Zhen-you Li ( $\triangle$ )

China NERIN Engineering Co. Ltd., Nanchang 330031, China

Email: 1248603495@qq.com

Ji-shan $\mathrm{He}$

Business School, Central South University, Changsha 410083, China

Meng-jun Wang

School of Civil Engineering, Central South University, Changsha 410083, China

\section{Introduction}

Internationally, the development process of project management is also the development process of international turnkey project management, as modern project management conforms to international turnkey projects. The development of modern project management can be divided into four stages. The first stage is the early phase, in which the budding era of modern project management started around World War II in the 1940s, when the project was managed by the Project Department Manager (also known as a functional manager or line manager) rather than being managed by a full-time professional project manager or a project management expert (Kerzner, 2006). The second stage is the phase of professional development. From 1960 to 1985, senior management in more and more companies began to seek new management methods and organizational structures that can quickly adapt to unpredictable environment (Kerzner, 2006). Thus, the International Project Management Association (thereafter referred to IPMA) was founded in 1965 and the Project Management Institute (thereafter referred to PMI) in 1969, both of which were milestones that conformed to the actual needs of the development of professional project management. It was the establishment and development of these two organizations that prepared the ground for modern professional project management. The third phase of modern project management is the mature application stage. Beginning in the $1990 \mathrm{~s}$, executives in many companies realized that the key point of project management was not how to implement it, but how to implement it quickly (Kerzner, 2006). By 2010, the project management of various industries had developed around the world, and brought huge returns. This was the mature period of project management. The fourth stage is the precise and accurate project management phase. From 2010 to date, facing increasing complexity and uncertainty of the projects, executives of project-driven companies realized that the implementation of project management requires sufficient precision and accuracy to maximize the performance level. Under such circumstances, Williams, Ferdin, and Croft (2014) suggested that data collection and handling and 
precise accuracy in the era of big data should be improved and applied to the project management maturity mode proposed in 2004, which thus help the company effectively continue achieving the project success and performance excellence, improving its core competences, which is the level of internationally core competences, in the international competing environment.

Over the years, international project management researchers have been exploring standards for project success, but so far there is no uniform standard for project success. Mackie (1984) defined the criteria for the success of the project: To complete the project within required project time, without exceeding the project budget, and the project quality to meet the design criteria. Eldin (1989) believed that the criteria for project success were the project is completed on time, within the project budget, and meets the project's technical and safety standards. Kerzner (2001) defines the criteria for project success as the project accomplishes the agreed time, cost and performance.

Other researchers believed that project success criteria included process operability after project initiation (Merrow, Phillips, \& Myers,1981), meeting project objectives (de Wit, 1988), customer satisfaction (Cheng, Proverbs, \& Oduoza, 2006), and project stakeholder satisfaction (Aaltonen, \& Kujala, 2010; Davis, 2014). For precise and accurate project management, both the work package level and project level must meet the above project success criteria.

The criteria for project success are measurable and can be used to determine whether the project is successful, and critical success factors (CSF) refers to the opportunity to improve the project's success. Rockhart (1982) described CSF for the first time on an information systems manager. Sanvido, Grobler, Parfitt, Guvenis and Coyle (1985) applied the concept of CSF to integrate construction project management process model configuration (Sanvido, Grobler, Parfitt, Guvenis \& Coyle, 1985). On the basis of project success criteria, Miller (1996) extended factors such as security, as well as organizational capability, project execution efficiency, shareholder value creation, customer perceived value, acceptance and use, and enhanced market position, and used them to study the CSF model for manufacturing projects.

Project excellence is a concept introduced by Westerveld (2003) to project management that is more demanding than the project success criteria and is widely used by the International Project Management Association (IPMA) for the annual International Project Management Excellence Awards Assessment and the European Integration Process in the post-evaluation of 14 mega-infrastructure projects (Hetogh, Baker, Staal-Ong, \& Westerveld, 2008). The IPMA continued to improve on it. By January 2016, three outstanding models were presented and issued. IPMAPEB-1.0: Project performance excellence baseline for achieving excellence in projects and programmes (International Project Management Association, 2016a). The
IPMA-ICBC-4.0: Individual competence baseline for project, programme \& portfolio management (International Project Management Association, 2015). The IPMA-OCB1.1: Organizational competence baseline for developing competence in managing by projects (International Project Management Association, 2016b). Project Excellence is the effect of the appreciation for the project processes, project results, as well as project team members, suppliers, subcontractors, and contracting partners, users and other stakeholders.

By studying the precise and accurate project management capabilities as a means, it is possible to improve the performance of the project to exceed the success criteria of the project after such capabilities are repeatedly optimized, thus forming the key success factors (CSF) for precise and accurate project management, such CSF are defined as the project internationally core competences. The gradual formation and continual improvement of internationally core competences depends on the optimization of project management abilities, and it will also facilitate the improvement of project success and excellence.

\subsection{The concept and meaning of internationally core competences}

"Enterprise core power" was firstly put forward by the famous American management experts Prahalad and Hamelin in their paper in 1990, "the Core Competence of the Corporation" (Prahalad, \& Hamel, 1990), where the core competences was defined as "an individual business can quickly make use of technical and production skills to adapt to changes in the environment" and as the "cumulative knowledge of the organization, unique capability of using enterprise resources in particular". Core competences of enterprises can be expressed in more detail, as the core competences of enterprises formed in a longtime period, and it was implicated in the internal quality of the enterprise. It was also exclusively unique for the enterprise, supporting competitive advantages of the enterprises in the past, present and future, and enabling the enterprises to achieve the initiative's core competencies in the long run competitive environment.

\subsubsection{The four elements that constitute the core} competences of the main contractor

In general, the core competences mainly includes four aspects, such as intellectual, technical, institutional, and cultural elements. The core competences of enterprises is established on the basis of core resources, and is implicated in the core products and services, such as intelligence technology, systems, and culture. The comprehensive advantages of the products and services will be reflected in the market. 


\subsubsection{The five features of core competences}

According to the definition of core competences of enterprises and its components, the following five significant features of enterprise core competences are:

(1) Value. The reason that the owners consume our services is that the value we offer has met consumer's demands, and the core competences should play an important role in the owner values.

(2) Exclusivity. The competence of a company must be unique and scarce, not owned by current and potential competitors.

(3) Non-repeatability. The core competence could not be easily learned and imitated by other companies.

(4) Difficulty of alternation. The capability is difficult to be alternated unless it is self-accumulated.

(5) Ductility. Generally, the company's core competences must be the foundation of the company's business, so that the company could produce a range of products and services and achieves scope economy.

The "internationally core competences" defined in this paper does not refer to the competences between countries. Instead, it refers to the internationally core competences of enterprises based on precise and accurate project management for the company or for companies in the international environment (not domestic market).

\subsection{The definition of precise and accurate project} management

\subsubsection{The definition of project targets is precisely measurable}

Traditional project management generally involves only the three requirements such as schedule, cost and quality, whilst in the cases of the precise and accurate project management, the goal of the project is divided into six rigid target dimensions: the time, cost, quality, health and safety environment and community relations (thereafter referred HSEC), contracts, and information and documentation requirements. Soft indicators include customer satisfaction, the full extent of communication among the project stakeholders including the degree of mutual respect, rationality of project management processes, as well as the results achieved, project results influence, and degree of reasonable resource utilization, project stakeholders' willingness on management excellence.

\subsubsection{All the project deliverables are precise and accurate}

Precise and accurate project management facilitates achieving the project objectives by submitting a series of deliverable, which are precisely and accurately measurable.

(1) Hardware deliverable, such as buildings, equipment;

(2) Software deliverable such as reports, documents;
(3) Intermediate deliverables, either hardware or software deliverable, which are constantly updated and developed as the project progresses.

1.2.3 The models and their parameters used in project life cycle are conducive to precisely and accurately planning, testing, implementing and monitoring, but all of these models and parameters are not necessarily quantified

(1) In all aspects of project planning and decisionmaking phase, such as planning and risk decisions on project marketing, project financing, project planning and process hazard analysis methods.

(2) In all aspects of project monitoring and control phase, such as supervision and control on schedule, cost, quality, HSEC, contracts, information and documents.

(3) In all aspects of project implementation and optimization phase, such as implementation and optimization of the design and engineering, procurement, as well as construction, commissioning and acceptance and the production preparation.

\section{Model configuration on internationally core competences}

2.1 Subdivided model components for internationally core competence

2.1.1 Model components on internationally core competences of risk decision based on precise and accurate project management for the main contractors

(1) Capability for strategic risk decision-making

In the strategic risk environment, risk decision-making capability is expressed in determining the proper mode of project management, as well as the proper strategies for tendering and contract negotiation, and the capability to precisely and accurately configure the sufficient capability of human resources and adequate number of man-hours required.

(2) Capability for financial risk decision-making

In financial risk environment, risk decision-making capability is expressed in the degree of precision and accuracy at the time of filing the application for project financing to ensure the required amount of financing, as well as reliable basis for estimates to ensure controllable systemic risks of the project.

(3) Capability for operational risk decision-making

In the operational risk environment, risk decisionmaking capability is expressed in delivering proper subcontracting planning to ensure the feasibility of the project execution plan (PEP), which is then approved by decision-making party and supervising and control party.

(4) Hazard risk decision-making capability 
In hazardous risk environment, risk decision-making capability is expressed in determining the correct risk analysis program to identify disaster risk management plan, whose purpose is to precisely and accurately control the process hazard risk from occurring.

\subsubsection{Model components on internationally core} competitiveness of monitoring and controls based on precise and accurate project management for main contractors

(1) Progress monitoring and control capabilities

Properly estimate the project schedule and duration, priorities and rational allocation of resources, and assess the progress of the project so that project schedules, plan and rational changes are under control.

(2) The cost monitoring and control capabilities

Based on reasonable estimate and assessment of the costs and decomposition of the costs of the project, ensure project costs plan and changes are under reasonable controls.

(3) Quality monitoring and control capabilities

Based on rational planning to quality and the evaluation of the project quality, ensure the project quality plan and changes are under rational control.

(4) HSEC monitoring and control capabilities

Based on rational planning for HSEC and the evaluation of the project HSEC, ensure the project HSEC plan and changes are under rational control.

(5) Contract supervision and control capabilities

Based on rational planning for contract and the evaluation of the project contracts, ensure the project contracting plan and changes are under rational control.

(6) Document and information monitoring and control capabilities

Based on rational planning for document and information and the evaluation of the project document and information, ensure the project document and information plan and changes are under rational control.

\subsubsection{Model components on internationally core}

competences of implementation and optimization based on precise and accurate project management for main contractors

(1) Design and engineering implementation of optimization capabilities

At all stages of project design and engineering, based on the proper implementation, optimization and coordination work as planned, ensure the design deliverables are delivered as required.

(2) Procurement implementation and optimization capabilities

In the various stages of the project procurement, based on the proper implementation of the procurement and optimization and coordination in accordance with procure- ment requirements, ensure the equipment, materials and services are delivered as required.

(3) Construction implementation and optimization capabilities

In each construction phase of the project, based on the proper implementation of the construction work, coordination and optimization, ensure the construction and mechanical completion of facilities are delivered as required.

(4) Implementation and optimization of commissioning and acceptance capabilities

In all phases of the project commissioning and acceptance, based on the proper implementation, optimization and coordination of commissioning and acceptance, ensure the project commissioning and acceptance services are delivered as required.

(5) Implementation and optimization of production preparation capability

In each production preparation stage of the project, based on the proper implementation, optimization and coordination of production preparation work, ensure the preparatory production work is delivered as required.

2.2 Model ratings for the internationally core competences based on precise and accurate project management of main contractors

(1) The main contractor strategic planning and decisionmaking capacities in the early stage of the project life cycle

In the early stages of the project, under a variety of risk environments such as project marketing, project financing, project strategic planning and project process hazard analysis, risk decision-making is the foundation for obtaining the project, assuring funding, and implementation planning and risk management planning. Strategic planning and decision-making capacities and their components ratings are listed in Table 1.

(2) The main contractor monitoring and control capacities in the project life cycle

In the full life cycle of the project, namely from the operational planning and risk decision stage to the completion of the project, project monitoring and controls on schedule, cost, quality, HSEC, contracts, information and documentation are the basis for determining the capability to achieve the expected goals of the project. The ratings of project monitoring and control capabilities are listed in Table 2.

(3) The main contractor implementation and optimization capabilities in project management life cycle

In the project implementation phase, the implementation and optimization of the project design and engineering, procurement, construction, commissioning, acceptance and production preparations are the basis for determining a smooth delivery as required. The ratings of project implementation and optimization abilities are shown in 
Table 1

Main Contractor Strategic Planning and Decision-Making Capability Ratings in the Project Early Stages for the Project Life Cycle

\begin{tabular}{|c|c|c|c|c|}
\hline Index category & Sub-index & $\mathrm{A}=$ Weight $(\%)$ & $\mathrm{B}=$ Scoring & Score $\mathrm{C}=\mathrm{A} \times \mathrm{B}$ \\
\hline \multirow{3}{*}{$\begin{array}{l}\text { 1. Strategic risk decision making } \\
\text { capability }\end{array}$} & 1.1 Capability of determining the project management model & 8 & $0-100$ & $0-8$ \\
\hline & 1.2 Capability of obtaining contract & 9 & $0-100$ & $0-8$ \\
\hline & 1.3 Capability of predicting project efforts & 8 & $0-100$ & $0-8$ \\
\hline \multirow{3}{*}{$\begin{array}{l}\text { 2. Financial risk decision-making } \\
\text { capability }\end{array}$} & 2.1 Capability of estimating the amount of project financing & 8 & $0-100$ & $0-8$ \\
\hline & 2.2 Capability of predicting systemic risk & 8 & $0-100$ & $0-8$ \\
\hline & 2.3 Capability of obtaining reliable cost estimate basis & 9 & $0-100$ & $0-8$ \\
\hline \multirow{3}{*}{$\begin{array}{l}\text { 3. Operational risk decision-mak- } \\
\text { ing capability }\end{array}$} & 3.1 Sub-contract planning capabilities & 9 & $0-100$ & $0-8$ \\
\hline & 3.2 Capability of computing total expected returns & 8 & $0-100$ & $0-8$ \\
\hline & 3.3 Capability of computing total expected risks & 8 & $0-100$ & $0-8$ \\
\hline \multirow{3}{*}{$\begin{array}{l}\text { 4. Hazard risk decision-making } \\
\text { capability }\end{array}$} & 4.1 Capability of determining the risk analysis methods & 8 & $0-100$ & $0-8$ \\
\hline & 4.2 Capability of identifying hazard process & 8 & $0-100$ & $0-8$ \\
\hline & 4.3 Capability of potential process hazard management & 9 & $0-100$ & $0-8$ \\
\hline Total score & & 100 & $0-100$ & $0-100$ \\
\hline
\end{tabular}

\section{Table 2}

Ratings on Monitoring and Control Capabilities for Main Contractors in the Project Life Cycle

\begin{tabular}{|c|c|c|c|c|}
\hline Index category & Sub-index & $\mathrm{A}=$ Weight $(\%)$ & $\mathrm{B}=$ Scoring & Score $\mathrm{C}=\mathrm{A} \times \mathrm{B}$ \\
\hline \multirow[t]{3}{*}{ 1. Progress monitoring and control capabilities } & 1.1 Capability of scheduling & 5 & $0-100$ & $0-5$ \\
\hline & 1.2 Capability of assessing progress & 5 & $0-100$ & $0-5$ \\
\hline & 1.3 Capability of controlling progress & 6 & $0-100$ & $0-6$ \\
\hline \multirow[t]{3}{*}{ 2. Costs monitoring and control capabilities } & 2.1 Capability of cost planning & 5 & $0-100$ & $0-5$ \\
\hline & 2.2 Capability of assessing costs & 5 & $0-100$ & $0-5$ \\
\hline & 2.3 Capability of controlling costs & 6 & $0-100$ & $0-6$ \\
\hline \multirow[t]{3}{*}{ 3. Quality monitoring and control capabilities } & 3.1 Capability of quality planning & 6 & $0-100$ & $0-6$ \\
\hline & 3.2 Capability of assessing quality & 6 & $0-100$ & $0-6$ \\
\hline & 3.3 Capability of controlling quality & 6 & $0-100$ & $0-6$ \\
\hline \multirow[t]{3}{*}{ 4. HSEC monitoring and control capabilities } & 4.1 Capability of HSEC planning & 6 & $0-100$ & $0-6$ \\
\hline & 4.2 Capability of assessing HSEC & 6 & $0-100$ & $0-6$ \\
\hline & 4.3 Capability of controlling HSEC & 6 & $0-100$ & $0-6$ \\
\hline \multirow[t]{3}{*}{ 5. Contracts monitoring and control capabilities } & 5.1 Capability of contract planning & 5 & $0-100$ & $0-5$ \\
\hline & 5.2 Capability of assessing contracts & 5 & $0-100$ & $0-5$ \\
\hline & 5.3 Capability of controlling contracts & 6 & $0-100$ & $0-6$ \\
\hline \multirow{3}{*}{$\begin{array}{l}\text { 6. Information and document monitoring and } \\
\text { control capabilities }\end{array}$} & 6.1 Capability of information and documents planning & 5 & $0-100$ & $0-5$ \\
\hline & 6.2 Capability of assessing information and documents & 5 & $0-100$ & $0-5$ \\
\hline & 6.3 Capability of controlling information and documents & 6 & $0-100$ & $0-6$ \\
\hline \multicolumn{2}{|l|}{ Total score } & 100 & $0-100$ & $0-100$ \\
\hline
\end{tabular}

Table 3.

According to the internationally core competence score results of Tables $1-3$, the grades are classified into four categories: excellent (90-100 points), good (75-89 points), qualified (60-74 points) and failed (less than 60 points).

\section{Results analysis and discussions}

According to the results of the assessment of the aforementioned Tables 1-3, the grades may be derived and the results are shown in Table 4.

According to the total score and deriving level of the 
Table 3

Main Contractor Implementation and Optimization Capabilities Ratings in Project Management Life Cycle

\begin{tabular}{|c|c|c|c|c|}
\hline Index category & Sub-index & $\mathrm{A}=$ Weight $(\%)$ & $\mathrm{B}=$ Scoring & Score $\mathrm{C}=\mathrm{A} \times \mathrm{B}$ \\
\hline \multirow{3}{*}{$\begin{array}{l}\text { 1. Engineering design implementation of } \\
\text { optimization capabilities }\end{array}$} & 1.1 Engineering design implementation capability & 7 & $0-100$ & $0-7$ \\
\hline & 1.2 Value engineering capability & 7 & $0-100$ & $0-7$ \\
\hline & 1.3 Engineering design coordination capability & 6 & $0-100$ & $0-6$ \\
\hline \multirow{3}{*}{$\begin{array}{l}\text { 2. Procurement implementation of } \\
\text { optimization capabilities }\end{array}$} & 2.1 Procurement implementation capability & 7 & $0-100$ & $0-7$ \\
\hline & 2.2 Procurement optimization capability & 7 & $0-100$ & $0-7$ \\
\hline & 2.3 Procurement coordination capability & 6 & $0-100$ & $0-6$ \\
\hline \multirow{3}{*}{$\begin{array}{l}\text { 3. Construction implementation of } \\
\text { optimization capabilities }\end{array}$} & 3.1 Construction implementation capability & 7 & $0-100$ & $0-7$ \\
\hline & 3.2 Construction optimization capability & 7 & $0-100$ & $0-7$ \\
\hline & 3.3 Construction coordination capability & 6 & $0-100$ & $0-6$ \\
\hline \multirow{3}{*}{$\begin{array}{l}\text { 4. Commissioning and acceptance } \\
\text { implementation of optimization } \\
\text { capabilities }\end{array}$} & 4.1 Commissioning and acceptance implementation capability & 7 & $0-100$ & $0-7$ \\
\hline & 4.2 Commissioning and acceptance optimization capability & 7 & $0-100$ & $0-7$ \\
\hline & 4.3 Commissioning and acceptance coordination capability & 6 & $0-100$ & $0-6$ \\
\hline \multirow{3}{*}{$\begin{array}{l}\text { 5. Production preparation implementation } \\
\text { of optimization capabilities }\end{array}$} & 5.1 Production preparation implementation capability & 7 & $0-100$ & $0-7$ \\
\hline & 5.2 Production preparation optimization capability & 7 & $0-100$ & $0-7$ \\
\hline & 5.3 Production preparation coordination capability & 6 & $0-100$ & $0-6$ \\
\hline \multicolumn{2}{|l|}{ Total score } & 100 & $0-100$ & $0-100$ \\
\hline
\end{tabular}

\section{Table 4}

Relationship of Internationally Core Competences and Performance Based on Precise and Accurate Project Management of Main Contractors \begin{tabular}{lllll}
\hline Internationally core competences & $\mathrm{A}=$ Weight $(\%) \mathrm{B}=$ Scoring & Capacity ratings & $\mathrm{C}=\sum\left(\mathrm{A}_{i} \times \mathrm{B}_{i}\right)$, total score & $\mathrm{D}=$ Evaluated scores by using
\end{tabular} IPMA-PEB-1.0

\begin{tabular}{|c|c|c|c|c|c|}
\hline Planning and decision-making & 40 & $0-100$ & $\begin{array}{c}90 \leqslant B \leqslant 100: \text { Excellent } \\
75 \leqslant B \leqslant 89: \text { Successful, } \\
60 \leqslant B \leqslant 74: \text { Qualified } \\
0 \leqslant B \leqslant 59: \text { Failed }\end{array}$ & & $90 \leqslant D \leqslant 100:$ \\
\hline Monitoring and control & 30 & $0-100$ & $\begin{array}{c}90 \leqslant B \leqslant 100: \text { Excellent } \\
75 \leqslant B \leqslant 89: \text { Successful, } \\
60 \leqslant B \leqslant 74: \text { Qualified } \\
0 \leqslant B \leqslant 59: \text { Failed }\end{array}$ & $\begin{array}{c}90 \leqslant C \leqslant 100: \text { Excellent } \\
75 \leqslant C \leqslant 89: \text { Successful, } \\
60 \leqslant C \leqslant 74: \text { Qualified, } \\
0 \leqslant C \leqslant 59: \text { Failed }\end{array}$ & $\begin{array}{c}\text { Award winners; } \\
75 \leqslant \mathrm{D} \leqslant 89 \text { : } \\
\text { Prize winners; } \\
60 \leqslant \mathrm{D} \leqslant 74 \text { : Finalists; }\end{array}$ \\
\hline Implementation and optimization & 30 & $0-100$ & $\begin{array}{c}90 \leqslant B \leqslant 100: \text { Excellent } \\
75 \leqslant B \leqslant 89: \text { Successful, } \\
60 \leqslant B \leqslant 74: \text { Qualified } \\
0 \leqslant B \leqslant 59: \text { Failed }\end{array}$ & & $0 \leqslant \mathrm{D} \leqslant 59:$ Failed \\
\hline
\end{tabular}

Table 5

Three Internationally Core Competences Category Indicators of the Main Contractor for Three Consecutive Years

\begin{tabular}{|c|c|c|c|c|c|c|}
\hline Annually & $\begin{array}{l}\text { Total revenues for } \\
\text { Overseas projects } \\
\text { (USD) }\end{array}$ & $\begin{array}{l}\text { Growth rate of revenues } \\
\text { for overseas projects } \\
(\%)\end{array}$ & $\begin{array}{c}\text { The new contract number } \\
\text { of overseas projects } \\
\text { (USD) }\end{array}$ & $\begin{array}{l}\text { The new contract growth } \\
\text { rate of overseas projects } \\
(\%)\end{array}$ & $\begin{array}{l}\text { Total profits for } \\
\text { overseas projects } \\
\text { (USD) }\end{array}$ & $\begin{array}{c}\text { Growth rate of profits } \\
\text { for overseas projects } \\
\text { (\%) }\end{array}$ \\
\hline 0th & A1 & NA & A3 & NA & A5 & NA \\
\hline $1 \mathrm{st}$ & B1 & B2 & B3 & B4 & B5 & B6 \\
\hline 2nd & $\mathrm{C} 1$ & $\mathrm{C} 2$ & $\mathrm{C} 3$ & $\mathrm{C} 4$ & C5 & C6 \\
\hline $3 \mathrm{rd}$ & D1 & D2 & D3 & D4 & D5 & D6 \\
\hline
\end{tabular}

internationally core competence of individual projects from Table 4, and the variance between the score and the comprehensive assessment of project performance evalu- ated by a qualified third-party using the Project Management Association (IPMA) IPMA-PEB-1.0 model (International Project Management Association, 2016) 
publicly released in January 2016, the relationship between the internationally core competences level based on the precise and accurate project management and the company project success can be established based on people and purposes, processes and resources and results of the project. In Table 4, only the Excellent and Successful in column of $\mathrm{C}=\sum\left(\mathrm{A}_{i} \times \mathrm{B}_{i}\right)$, total score, and Award winners and Prize Winners in the column of $\mathrm{D}=$ Evaluated scores by using IPMA-PEB-1.0 can be defined as project success, and the corresponding CSF can be defined as the internationally core competences of the model.

Since 2013, the "Engineering News Record" (ENR) has published annually the ranking of the largest 250 international contractors, and the "Top 250 International Contractors" is rated based on international contracting company turnover outside the home country, which indicates international engineering business development and implementation of national strength "going out" strategy performance of the company. In this paper, as shown in Table 5, three types of indicators characterize the level of international competences. The first indicators are new contract amounts and the growth rate of overseas projects, which represent the company's capability to obtain projects in the overseas markets and the performance of project strategic planning and decision-making abilities. The second category indicators are the revenues and the growth of overseas projects, which indicate the company's capabilities to implement and optimize such projects. The third category indicators are total profits and the growth rate of profitability of the overseas projects of the company, which indicate the performance of the project monitoring and control capabilities.

If the calculated B2, C2, D2, B4, C4, D4, B6, C6, D6 are all positive, it indicates that the internationally core competences of the main contractor is continuously improved. By comparing the cumulative annual indexes for each single project listed in Table 4 with the annual indicators for three consecutive years listed bin Table 5, it can be found that the continuous project success of the international main contractor directly facilitates the continuous improvement of its internationally core competences.

\section{Conclusions}

In this article, components of the model for internationally core competences based on precise and accurate project management have been defined and studied, and the model on internationally core competences has been configured. The methods for model evaluation and scoring have been developed by referring the IPMA-PEB-1.0 and actual project performance. The methods can guide the international projects and drive the main contractor to improve each link of internationally core competences in three areas, including project planning and decision-making, monitoring and control, implementation and optimization in the project life cycle, so as to achieve continuous success of the projects. Consequently, the main contractor continuously improves its internationally core competences level and realizes virtuous operational circle.

\section{References}

Aaltonen, K., \& Kujala, J. (2010). A project life-cycle perspective on stakeholder influence strategies in global projects. Scandinavian Journal of Management, 26(4), 381-397.

Cheng, J., Proverbs, D., \& Oduoza, C. F. (2006). The satisfaction levels of UK construction clients based on the performance of consultants. Engineering, Construction and Architectural Management, 13(6), $567-583$

Davis, K. (2014). Different stakeholder groups and their perceptions of project success. International Journal of Project Management, 32(2), 189-201.

de Wit, A. (1988). Measurement of project success. Project Management, 6(3), 164-170.

Eldin, N. N. (1989). Measurement of work progress: Quantitative technique. Journal of Construction Engineering and Management, 115(3), 462-474.

Hetogh, M. J. C. M., Baker, S., Staal-Ong, P. L., \& Westerveld, E. (2008). Managing Large Infrastructure Projects-Research on best practices and lessons learned in large infrastructure projects in Europe. AT Osborne BV.

International Project Management Association. (2015). Individual competence baseline for project, programme, and portfolio management. Retrieved from http://products.ipma.world/product/icb/

International Project Management Association. (2016a). Project excellence baseline for achieving excellence in projects and programs. Retrieved from http://products.ipma.world/product/peb

International Project Management Association. (2016b). Organizational competence baseline for developing competence in managing by projects. Retrieved from http://products.ipma.world/product/ocb/.

Kerzner, H. (2001). Project management-A systems approach to planning, scheduling, and controlling. 7th ed. New York: John wiley \& Sons, Inc.

Kerzner, H. (2006). Project management-A systems approach to planning, scheduling, and controlling. Hoboken: John Wiley \& Sons.

Mackie, D. (1984). Engineering management of capital projects: a practical guide. Toronto: McGraw-Hill Ryerson Limited.

Merrow, E. W., Phillips, K. E., \& Myers, C. W. (1981). Understanding cost growth and performance shortfalls in pioneer process plants. Santa Monica, CA: Rand Corporation.

Miller, K. L. (1996). Critical success factors for engineering and managing strategic projects in a manufacturing environment (Dissertation for the Doctoral Degree). Cleveland: Case Western Reserve University.

Prahalad, C., \& Hamel, G. (1990). The core competence of the corporation. Harvard Business Review, 68, 79-91.

Rockhart, J. (1982). The changing role of the information systems executive: a critical success factors perspective. Sloan Management 
Review, 24(1), 3-13.

Sanvido, V., Grobler, F., Parfitt, K., Guvenis, M., \& Coyle, M. (1985).

Critical success factors for construction projects. Journal of

Construction Engineering and Management, 118(1), 94-111.

Westerveld, E. (2003). The project excellence model: Linking success criteria and critical success factors. International Journal of Project Management, 21(6), 411-418.

Williams, N., Ferdinand, N. P., \& Croft, R. (2014). Project management maturity in the age of big data. International Journal of Managing Projects in Business, 7(2), 311-317. 